\title{
A PRACTICAL METHOD FOR THE DETERMINATION OF BUSINESS FACT
}

\section{Philit G. Phillips † \\ I. Business and Legal Truth}

Rules of evidence are so thoroughly instilled into the ordinary lawyer that they are a part of his conscious and subconscious makeup. ${ }^{1} \mathrm{He}$ generally looks upon them not only as a principle for the trial of jury cases, but as an accurate method for any approximate determination of fact. When applied in some fields of endeavor these rules appear ludicrousimagine a rift in the marital relation because of the constant wrongful use of opinion evidence by the lawyer's wife. (It has happened!) The business man, accustomed to his own peculiar method of fact determination, thinks the lawyer's method unsound, even as applied to jury cases. They speak different languages. Is an interpreter needed, or should each try to comprehend the other's method of reasoning?

Imagine, if you will, a plaintiff suing a defendant for the contract price of a large shipment of bamboo skewers. The defense to the action is that the goods are not merchantable. Days are spent in trial. The plaintiff's experts swear by all that is holy that the skewers are of unusual excellence, point out their scientific value and their absolute salability; the defendant's experts by the same tokens swear that the skewers are poor, scientifically unsound, and can be sold in no event. The defendant had produced two or three housewives to testify, but every question they were asked was excluded. The jury ponders, listens to impassioned argument by counsel and to a formal charge by the learned trial judge regarding burden of proof. They deliberate, and everyone of them is certain he knows no more about the merchantability of the particular skewers than if no evidence had ever been taken. "There is no difficulty, the defendant has not proven that the skewers were not merchantable, return a verdict for the plaintiff' a mythical lawyer or a bailiff not quite mindful of his legal duties tells them. But our supposed jury is over-inquisitive and over-intelligent. They know the skewers were or were not merchantable, and decide to learn the truth. Surreptitiously they go out and attempt to sell the skew-

$\dagger$ A. B., I924, LL.B., I927, Harvard University; Author of A Business Tribunal for Corporate Re-organization (I933) in HaRv. Bus. REv. I78; Collaborator, Code of ARBITRAtron: Practice and Procedure; member of the Massachusetts Bar; contributor to legal periodicals.

${ }^{1}$ Cf. Wigmore, Administrative Boards and Commissions: Are the Jury-Trial Rules of Evidence in Force for Their Inquiries? (1922) I7 ILL. L. Rev. 263. 
ers on the open market, or better still give them to some good skewer salesman to sell. They find conclusively that they cannot be sold, the trade, when approached as business men rather than as testifying experts, admit their utter worthlessness. They return a verdict for the defendant.

After our mythical lawyer recovers from his shock, he would inform us that the verdict would be promptly overturned, and the jury chastized for their gross violation of duty. A mythical business man might inquire as to whether the jury had not really reached a just verdict, and had not determined the business truth of the matter, but would be buried under a mass of legal terminology involving rights of cross-examination, larger words if necessary, and a conclusion that the evidence presented by the parties at the trial was all the jury could use in reaching their verdict. What matter that the jury was desirous of reaching "business truth"; "legal truth" is what the evidence shows. And the mythical lawyer would doibtless be right in his contention that the jury could not go outside for facts. The rules of evidence developed for jury trials are firmly established and may conceivably provide the only equitable method of jury trial-but the same arguments are hand-made demonstration of the limitations of jury trial in connection with complicated types of business facts, and show no reason for the same methodology to be applied to other systems of resolving controversies and disputes.

"Business truth" and "legal truth" 2 are all too frequently different, and certainly are arrived at by an entirely different method of logical analysis. The needs of the two are dissimilar. ${ }^{3}$ In purchasing dresses hearsay evidence may be exactly what is necessary. A statement by Mrs. Jones that: "All the women at Mrs. Smith's tea said they liked them", might mean far more than any scientific expert's evidence about their quality in determining merchantability for purchase purposes. Yet in the jury trial of the same issue, such testimony would be promptly and, it is submitted, properly excluded. The scientist would be disgusted at the logical method used by both lawyers and business men; progress could be effectively stifled by the use

${ }^{2}$ Cf. Isaacs, On Business Facts (1932) 6 CIn. L. Rev. I ; Powell, The Logic and Rhetoric of Constitutional Law (I9I8) J. of PhIl., Psych. \& Scientific Metrods 645.

3 "Suppose that John Smith is suspected of being a thief. The allegation reaches his fiancee, his employer, a grand jury and eventually a petit jury. The first would reach her conclusions on the subject in her own way. The employer might well say to himself: 'I am only employing the man, not marrying him. I can give him the benefit of the doubt and watch him.' Or he might feel that he had heard enough to justify the conclusion that he should not keep the man in his employ. The grand jury, hearing the same evidence as that placed before the others, might decide that however reasonable that conduct might have been in view of their purposes, the man either should or should not be held for trial. And finally, it is quite possible that though one would be foolish, under the circumstances, to marry him or even employ him, it would be equally foolish without better evidence to convict him. Thus for some purposes the truth found is in effect 'guilty' and for others 'not guilty'. The 'absolute' truth has not been touched in any of these cases-and in human affairs probably cannot be." Isaacs, How Lawyers Think (Ig23) 23 CoL. L. REv. 555, 557. 
of hearsay evidence or the doctrine of res judicata. The moralist in turn often determines truth by a broad utilitarian test, and thinks of truth as that which will prove most beneficial to all concerned. 4 If a jury were in doubt whether a defendant committed a tort, the solution according to the moralist's "logic" is simple-he did not do it; a conclusion which would benefit everyone far more than finding him culpable. And many other methods of determining "truth" could be cited. No one, except a logician, is really interested in pure truth. What we are attempting in all cases is to find merely an approximate determination of fact to fit the individual need and situation.

But even an approximate definition of fact may be difficult, ${ }^{5}$ and differ according to need. The legal method of trial to determine fact has no logic behind it unless the needs of trial and the reason therefor are present.

It is unfortunate that the rules to govern jury trials are called "The Rules of Evidence". The name has too all-inclusive a ring about it; it is too majestic and too sweeping when we consider that these rules are merely "the method of aiding an untrained and inexperienced body of triers, newly selected ad hoc for each trial and functioning in all kinds of litigation of infinite variety" "; rules adopted as a result of the rigidity of common law procedure, lack of confidence in jurors, and the contentiousness of legal proceedings in general. The limitation should be "Rules of Evidence for Jury Trials". It must be frankly recognized that the determination of fact is not the primary aim of our jury rules of evidence. Otherwise our jury could have gone outside to get evidence about these particular skewers. The law in its evolution has never stopped to ask: "What kind of fact is needed to prove a case?"; but rather the law has said: "You can have this kind of proof and only this kind", and soundly enough because it is the only type adapted to our method of trial. A "business logic" approach would be to see what kinds of fact are needed, and to that adapt rules of evidence. This, to be certain, could not be done for jury trials, but it might well be adapted to other methods of fact determination. Should our established rules of hearsay, opinion evidence, privilege, outside determinations, judicial notice, for example, apply to commercial arbitrations?

${ }^{4}$ Cf. Fullerton, An Introduction to PHIlosophy (I9z2) 296ff. "Objective evidence and certitude are doubtless very fine ideals to play with, but where on this moonlit and dream-visited planet are they found?" See passim JAMEs, THE WILL to BeLIEve (I897).

${ }^{5}$ Cf. Henderson, Approximate Definition of Fact (1932) I4 U. of Calif. Publications in Philosophy i 79 .

${ }^{\circ}$ Wigmore, supra note I, at 263 , "Our law of evidence is largely a product of the jury system. The purpose of its exclusionary rules is to keep from the jury not only all that is irrelevant, but also much that, although relevant, is remote, or collateral, or non-probative, and, therefore, tends to mislead or confuse." Pound, J., dissenting in Carroll v. Knickerbocker Ice Co., 218 N. Y. 435, 447, II3 N. E. 507, 5 II (IgI6). 


\section{Determination of Fact ex parte in Commercial Arbitrations}

Suppose in the skewer case set forth an arbitrator instead of a jury were to determine the issue. Suppose he were an expert in ordinary skewers, but not in bamboo skewers which were being introduced on the market for the first time. Suppose further that he could determine little from the conflicting opinion of alleged experts (none of whose opinions the arbitrator considered equal to his) or from the conflicting statements of the parties. His natural inclination would be to make an expert survey and to attempt to sell them himself and through his own salesmen. This was done in Berizzi Co. v. Krausz, ${ }^{7}$ with the result that the New York Court of Appeals vacated an award based on the ex parte investigation showing that the goods were unmerchantable. And this without the objecting party being required or able to prove that the goods were in fact merchantable or that there was any business evidence to this effect. ${ }^{8}$ The Court of Appeals stated:

"We think that the conduct of this arbitrator was misbehaviour prejudicing the rights of one of the parties . . . what was contemplated was a hearing. What ensued was a default." 9

Doubtless what ensued was not a hearing, if "hearing" is synonymous with "trial"; sed non sequitur it was a default. The court further states:

"There would be little profit in fixing a time and place of hearing, if the arbitrators were at liberty when a hearing was over to gather evidence ex parte, and rest their award upon it." 10

There would be no point in fixing the time for a hearing if the parties expected a jury hearing; but there is perfect consistency in granting the parties a right to be heard, and also allowing an expert of the parties' own choosing to decide the questions of fact in a fair manner if he deems it worthy of an approximate determination of fact. By what right do our courts assume that the business man desires something analogous to a trial when he submits his dispute to arbitration? Certainly the modus operandi of a determination of fact by a jury composed of men selected by lot from which is excluded anyone who knows the slightest thing about the subject matter should not be the same as that followed by experts selected by parties to the dispute because they possess knowledge of the subject matter or know

\footnotetext{
${ }^{7} 239$ N. Y. 3I5, I46 N. E. 436 (1925). The case is adversely criticized in Note (I925) 25 CoL. L. REv. 822, 826; (1925) 34 YALE L. J. 905; and approved in (rg25) 20 InI. L. REv. 308. The decision of the Appellate Division which was reversed by the Court of Appeals in the principal case is approved in Wheless, Arbitration as a Judicial Process of Law (I924) 30 W. VA. L. Q. 209. Cf. (I93I) I72 L. T. 72.

${ }^{8}$ The unfairness of this rule is pointed out in Moore v. Butlin, 7 L. J. Q. B. (N. S.) 20 (1837); cf. Mercer v. Reid, 47 T. L. R. 574 (I93I), aff'd 48 T. L. R. 33l (I93I).

- Berizzi v. Krausz, supra note 7 , at $318,320,146$ N. E. at $437,438$.

${ }^{10} I d$. at 319, I46 N. E. at 437.
} 
how to determine it in a business-like manner-unless, without consideration of needs, the law arbitrarily says: "This is all you can have".

Arbitration is a growing force in the determination of business disputes. Numerous reasons are assigned for its growth, and its use in New York City is surprising. Some turn to it for privacy, some for speed or economy.11 But even if we had private, speedy, cheap jury trials, there would still be a great number who would turn to arbitration because they can obtain thereby an expert business judgment of the facts involved. Arbitrators are becoming chosen to greater extent because they are the outstanding experts in the field of dispute, and not because they will act as champions of the party choosing them. Instead of burdening them with anachronisms of trial, the law should synthesize the best of legal and business logic and allow arbitrators to utilize it. Legal rules of evidence in force for historical reasons, or for their special fitness to juries, should not be applied when there is no logical business reason for them.

Examine the methods built up and enforced by certain popular trade tribunals and we find none of the ordinary legal anachronisms of trial. ${ }^{12}$ For example, in the ordinary hide and leather arbitration in New York, merchandise is submitted to experts who are uninformed of the identity of the parties, who submit their contention anonymously, and who determine quality or quantity at least in an expert business manner. The ordinary fur arbitration in New York City consists of a five or ten minute explanation of the terms of the contract by the parties and then a thorough ex parte examination of the merchandise by the expert arbitrators. And trade tribunals use this method of fact determination to greater extent. ${ }^{13}$ Business men naturally utilize these arbitrators because a business-like solution of a business problem is thereby evolved. When lawyers represent their clients at such proceedings the former are at a loss and invariably seek to prolong the proof of documents and statements by witnesses and minimize the actual examination of merchandise. From the author's own observation a good trial lawyer is not always a good man to try a case before a commercial arbitration board-the two do not speak the same language, and certainly do not use the same logic. Many a good arbitration case has been lost because the lawyer insists on his legal evidence and attempts to

11 There are many excellent summaries of the advantages of arbitration. For an unusually clear statement see Sturges, Commercial Abitration or Court Application of Common Law Rules of Marketing? (I925) 34 YaLE L. J. 480.

12 The Year Book on Conmarerctal Arbitration (i927) Oxford University Press, New York City, prepared by the American Arbitration Association, contains a very complete summary of the various rules of arbitration procedure in force in the United States.

${ }^{23}$ And in many trades arbitration "by correspondence" without an oral hearing is had. See, for example, the Arbitration Rules of the American Fruit and Vegetable Shippers Association, and the Arbitration Rules of the Interstate Cotton Seed Crushers Association, Inc. 
"soft pedal" the really relevant business facts which his client is so anxious to present.

Nevertheless Berizzi v. Krausz is generally the law. ${ }^{14}$ If the parties consent to an ex parte examination the law will not object. ${ }^{15}$ In fact in many states parties may, by contract, provide a procedure for the arbitrators to follow, and this with but few exceptions will be fully respected by the courts. ${ }^{16}$ This is generally accomplished by the agreement to arbitrate according to definite arbitration rules. But the arbitration rules are all too often drafted by lawyers according to old jury rules. ${ }^{17}$ The business world at large rarely includes any procedure in its arbitration agreements. The agreement generally provides for "arbitration" but nothing more and rules of evidence are sadly neglected even in agreements and rules providing for detailed arbitration procedure. For example, few provide for an independent investigation by arbitrators. ${ }^{18}$ When the arbitrators propose such an examination at the hearing, and they most frequently do, one or the other of the contestants invariably objects, especially if lawyers are present. The author has witnessed countless examples of this, and learned of many more where the arbitrators nevertheless made an ex parte examination-and "no one was the wiser". ${ }^{19}$ The plaintiff in Berizzi $v$. Krausz was unfortunate in that the information of the arbitrator's actions came to light.

There are few decisions in other states not in accord with Berizzi $v$. Krausz where the arbitration resembled an appraisal. Thus in Bangor Sav-

Is See cases cited infra notes 27,28 , and 29 .

${ }^{15}$ Robins Silk Co. v. Consolidated Piece Dye Works, 224 App. Div. 83,229 N. Y. Supp. 500 (I928), aff'd 251 N. Y. 87, 167 N. E. I8I (I929) ; cf. Ketcham v. Odd Fellows, 59 Pa. Super. 213 (I915).

${ }^{10}$ Finsilver v. Goldberg, Maas \& Co., 253 N. Y. 382, 17I N. E. 579 (1930) ; Matter of Palmer \& Pierce, Inc., I95 App. Div. 523, I86 N. Y. Supp. 369 (Ig2I) ; Procter \& Gamble Co. v. Blakely Oil Co., I37 Ga. 407, 73 S. E. 378 (IgII) ; Fernandes Grain Co. v. Hunter Grain Co., 2I7 Mo. App. 187, 274 S. W. 900 (1925); cf. Katakura \& Co. v. Vogue Silk Hosiery Co., $307 \mathrm{~Pa} .544$, 16I Atl. 529 (1932).

${ }^{17}$ In Illinois, rules must be approved by a court to be legally effective. Ir工. Rev. STAT. (Cahill, I933) c. I0, $\$ 2$.

${ }^{18}$ There are, however, certain rules which provide for the $e x$ parte examination of merchandise; for example, Rules of the National Association of Importers of Hides and Skins; or for ex parte chemical examinations, for example, Rules of the United States Sheliac Importers' Association, Inc. In five states at least (California, Idaho, Nevada, New York and North Dakota) the receiving of ex parte information would have to be done surreptitiously. For in those states the criminal laws incorporate the rule of Berizzi v. Krausz by providing that any arbitrator who willfully receives any communication, book, paper, instrument, or information relating to a cause or matter before him, except according to the regular course of proceeding upon the hearing of that cause or matter, is guilty of a misdemeanor.

${ }^{10} \mathrm{~A}$ recent interesting and very pointed case came to our attention in which a lawyer of repute was acting as an arbitrator in a theatrical case. Under the contract the management agreed to indemnify the actor for any actual loss to his personal effects sustained during the performance. A pair of black trousers was damaged beyond repair during the performance, and the actor claimed damages not only for the trousers but for the entire suit as well. $\mathrm{He}$ presented his tailor to testify that it was impossible to match black woolens perfectly-as was necessary in a well-dressed actor. The management scoffed at the idea, and intimated 
ings Bank v. Niagara Fire Insurance Co., ${ }^{20}$ the court stated: "The arbitrator may, for his own information, ask information from persons whose capacity to form an accurate opinion concerning the subject matter he relies upon", and a few other cases would seem to support this view. ${ }^{21}$ In other states it would seem that the independent investigations are proper if the parties are later notified and have a chance to cross-examine any evidence received. ${ }^{22}$ In California the rule formerly was that so long as the arbitrator formed his own opinion the independent investigation was not fatal. ${ }^{23}$ It is submitted that the rule in Berizzi $v$. Krausz is unsound, and that arbitrators should be permitted to make independent investigation. No award should be upset unless a fundamental prejudice to the complaining party can be shown.

Berizzi v. Krausz did allow some exceptions, proving that there is nothing so fundamental about its rule that an opposite one would be against public policy. The court said:

"We do not mean, of course, that an award will be vitiated by investigations in the absence of the parties if directed towards facts of trifling importance or facts of such a nature as to preclude reasonable contest. This may include views or the ascertainment of physical conditions notorious and permanent." ${ }^{24}$

Thus, the conditions of rollers in a mill, alleged to have damaged merchandise, were held a "physical condition, notorious and permanent", ${ }^{25}$ permitting ex parte examination; and confirmatory tests, made ex parte by the arbitrators of tests made or authorized at the hearing, were not fatal to an

that the tailor and actor were both angling for a new suit. The arbitrator unhesitatingly decided in his own mind that the actor's claim was preposterous, but did, before rendering his final award, consult his own tailor on the point. The latter agreed perfectly with the actor, whereupon the arbitrator found ample corroboration from woolen manufacturers and discovered the trade reason why black woolens cannot be matched to satisfaction. Perfect justice was undoubtedly accomplished in the case; though it is just as certain that under Berizzi v. Krausz the award would have been vacated. We doubt whether by any other method than an outside investigation the real truth could have been obtained. Were the normal trial method followed, each side could undoubtedly have found experts to testify as desired about matching wool, and the arbitrator would have been even more in doubt as to the real situation than had no testimony been taken.

${ }^{\infty} 85$ Me. 68, 26 Atl. 991 (1892).

${ }^{a}$ Straw v. Truesdale, 59 N. H. 109 (1879) ; Dechant v. Globe etc. Fire Ins. Co., I94 Wis. 579,2 I7 N. W. 322 (I928).

${ }^{2}$ Christianson v. Norwich Fire Ins. Society, 84 Minn. 526, 88 N. W. I6 (1901).

${ }^{23}$ Simons v. Mills, 80 Cal. II8, 22 Pac. 25 (1889)

- Supra note 7, at 320,146 N. E. at 438 . This exception, or perhaps even a broader one, has been recognized since early times in Pennsylvania. "If referees make enquiries abroad, to ascertain for their own satisfaction, the price of work, or the truth of any other matter, which may be said, comparatively, to be of a public nature, this, so far from being irregular, would be highly commendable. But it is a very different case, when they proceed separately to examine a witness, who has been produced by one of the parties, although the evidence relates only to those general points. The adverse parties should have an opportunity of cross-examining the witness." Chaplin v. Kirwan, I Dall. 204 (Pa. 1786).

${ }^{2}$ Robins Silk Co. v. Consolidated Piece Dye Works, supra note 15. 
award. ${ }^{26}$ The courts of New York now apparently recognize the business hardships of Berizzi v. Krausz, and are attempting to break away from its rigors.

We do not mean that arbitrators should surreptitiously consult the parties, ${ }^{27}$ or hear witnesses ex parte at the suggestion of one side; ${ }^{28}$ this would obviously be unfair. Business logic does not call for such tactics. Neither do we mean that arbitrators should obtain ex parte the opinions of others on the case, ${ }^{29}$ and without determining the facts themselves adopt

${ }^{\text {ca }}$ Matter of Gerli \& Co. v. Heineman, 258 N. Y. 484, I80 N. E. 243 (1932) ; Horowitz v. Kaplan, 221 App. Div. 567, 224 N. Y. Supp. 498 (I927). Contra: McKinney v. Page, 32 Me. 5 I3 (I85I).

${ }_{\pi}$ Such consultation will vitiate an award without the necessity of showing that the conference was prejudicial. Rand v. Peel, 74 Miss. 305, 2I So. Io (I8g6). The language of the cases would indicate such conference vitiates the award ipso facto; but Whitney v. Church, 9I Conn. 684, Ior Atl. 329 (1917), held the party conferred with could not complain. And in Thompson v. Edwards, $220 \mathrm{Ky} .239,294 \mathrm{~S}$. W. I095 (I927) consultation ex parte of one party's attorney was held not fatal without showing prejudice to the other, the complaining party. Where one party submitted a new statement of his case ex parte the award was vacated, without the proof of prejudice. Cleland v. Hèdly, 5 R. I. I63 (1858); the furnishing of legal citations ex parte had the same effect in Hewitt v. Village of Reed City, 124 Mich. 6, 82 N. W. 616 (I900) ; receipt of a paper from one party-even after the arbitrator's mind was fully made up, and not changed by the paper-was cause for vacation of the award in Jenkins v. Liston, I3 Gratt. 535 (Va. I856); showing an arbitrator ex parte a newspaper vacated an award without the complaining party being required to show there was anything prejudicial therein in Wilkins v. Van Winkle, $78 \mathrm{Ga}$. 557, 3 S. E. 76I (I887); showing a map likewise proved fatal in Whitehair v. Kansas Flour Mills Corporation, I27 Kan. 877, 275 Pac. I90 (1929) (citing Berizzi v. Krausz). The cases in this paragraph go far; and it is submitted that where the complaining party is unable to prove prejudice by the ex parte communication the award should not be vacated. Cf. Small v. Trickey, 4I Me. 507 (1856). And certainly if the other party can show affirmatively there was no prejudice in the ex parte communication, the award should be allowed to stand.

${ }_{23}$ And the courts so hold-without proof of prejudice. Catlett v. Dougherty, II4 Ill. 568,2 N. E. 669 (1885). But where the arbitrators on their own initiative consult witnesses outside the regular hearing, the remarks about Berizzi v. Krausz contained in the text are partially applicable, and probably no award should be vacated unless prejudice can be shown, and clearly the award should stand when the non-objecting party can show no prejudice. The latter doctrine was advanced in Jackson v. Roane, 90 Ga. 669, I6 S. E. 650 (I893). Many cases, however, hold such consultation of a witness ipso facto fatal to the award. Hickey v. Grooms, 4 J. J. Marshall I25 (Ky. I830) ; Rosenau v. Legg, 82 Ala. 568, 2 So. 44I (I887) ; Larson v. Nygaard, $148 \mathrm{Minn}$. I04, I80 N. W. 1002 (I92I). Of course, there are certain circumstances where the outside consultation of witnesses might be fatal, e. g., in Sullivan v. Frink \& Co., 3 Iowa 66 ( 1856 ), the defendant admitted liability in a tort case and the arbitrators announced that they would therefore hear only evidence of damage. After the hearings were closed, the arbitrators independently consulted the witnesses whom the plaintiff was to present to prove liability, and damages obviously punitive in nature were awarded. Held, (and, under the facts, it is submitted, properly) the award should be vacated. On the other hand, there are a few liberal decisions where the court examined all the facts and allowed the award to stand; e. g., the consultation of a handwriting expert by the arbitrators was held not fatal in Redman v. St. Joseph Hay and Grain Co., 209 Mo. App. 682, 239 S. W. 540 (1922) and the rehearing of a witness unknown to the parties was held not fatal in Plumner v. Sanders, 55 N. H. 23 ( 1874 ). The Pennsylvania rule would seem to be that receiving ex parte a party's statement, or examining a witness not in the presence of the parties, will ipso facto vitiate an award. Speer v. Bidwell, $44 \mathrm{~Pa} .23$ (I862). Suppose one arbitrator has knowledge of facts which he does not communicate to the parties, but tells the other arbitrators after the hearing is closed? On the jury analogy, of course, the award would be vacated; on the theory of "expert judge" the award would stand. Cf. Straw v. Truesdale, supra note 2I; Jones v. Northern Assurance Co., I82 Ky. 70I, 207 S. W. 459 (IgIg).

${ }^{2}$ And the courts correctly so hold. David Harley Co. v. Barnefield, 22 R. I. 267,47 Atl. 544 ( 1900$)$. The parties are certainly entitled to the judgment of the arbitrators. Sometimes this may cause hardship, however, as for example when a complicated set of 
such opinions as their award. But arbitrators should be able to reach a business-like verdict by business-like methods of fact finding.

English cases frequently, in spite of more rigid rules regarding arbitrations, recognize "commercial arbitrations" as apart from the ordinary trial or ordinary arbitration, and allow business usages and custom to prevail in the arbitrators' determination of fact. ${ }^{30}$ No American decision has, however, adopted the English view.

Even in the United States the arbitration agreement may be such as to indicate that the expert arbitrators are to decide the case without the introduction of any evidence, let us say as to value or quality of merchandise. Such agreements will be enforceable, and the arbitrators may decide the case on their own knowledge. ${ }^{31}$ But suppose the arbitrator, in anticipation of the proceeding makes himself an expert, and searches for evidence so as to be better enabled to judge the results of the trial. Suppose the arbitrator in Berizzi $v$. Krausz had made an independent investigation of bamboo skewers before the hearing, and then had listened without prejudice to all the evidence presented? On the analogy to jury trial, of course his award would be vacated, on the analogy to the "expert" arbiter, the award would stand. The law is hazy and generally the courts when called upon to decide the question skillfully evade it. ${ }^{32}$ : Oddly enough, in early jury history

figures arises and the arbitrators consult an accountant and bodily adopt his judgment. This was held fatal in Shipman v. Fletcher, 82 Va. 60I (I886). But obtaining an opinion of a lawyer by non-legal arbitrators under a submission where they were bound to find according to law, and where the opinion was given only in answer to a hypothetical question, was held not fatal to the award in Stone v. Baldwin, 226 I11. 338, 86 N. E. 890 (rg07). There is a generally recognized exception in construction cases. Where the general engineer is named as arbitrator in the contract, he may adopt the opinion of the engineer on the job. Royal Indemnity Co. v. Batson-Cook Co., 37 Ga. App. 797, I42 S. E. 210 (1928). Cf. also Whitney v. Church, supra note 27 , holding that if the arbitrator's conduct is made known to the parties and they do not protest, the award will stand. In England it is a common practice for a lay board of arbitrators to employ a "legal assessor" whose function it is to advise them on all legal questions arising during the arbitration and on whose opinion they are free to rely. See the Arbitration Rules of the British Empire Chambers of Commerce; $c f$. Westwood \& Co. v. Cape of Good Hope Government, 2 T. L. R. 667 (I886). (I92I).

${ }^{30}$ See, for example, French Government v. S.S. Tsurushima Maru, 37 T. L. R. 96I

${ }^{31}$ Gammon v. McClannahan, 204 Ky. 67, 263 S. W. 770 (1924); Wiberly v. Matthews, gr N. Y. 648 (1883) ; cf. Cobb. v. Dolphin Mfg. Co., I08 N. Y. 463 , I5 N. E, 438 (I888); McManus v. Philadelphia, 20I Pa. 632, 5I Atl. 322 (1902). And see the interesting analogy in administrative immigration law: "But the statute does not require inspectors to take any testimony at all, and allows them to decide on their own inspection and examination the question of the right of any alien immigrant to land." Nishimura Ekiu va United States, 142 U. S. 65I, 663, I2 Sup. Ct. 336, 340 (I892).

${ }^{3}$ In re American Trading Co., N. Y. L. J., Feb. II, 1926, $a f f^{\prime} d 216$ N. Y. Supp. 793 (1926), held such action would be fatal if by an impartial arbitrator or umpire, but not for a "party-selected arbitrator"; Matter of Elmhurst-Gleane Corporation, N. Y. L. J., Oct. 3I, I93I, did not consider such conduct fatal but the facts of the case show the parties had knowledge of the arbitrator's conduct. In Moshier v. Shear, I02 I11. I69 (I88I) the jury analogy was absolutely followed and an award vacated without the complaining parties being required to prove prejudice because of the facts learned prior to the arbitration. The court said: "After being selected it is the duty of an arbitrator, like a juror, to act . . . on the evidence adduced before them at trial and what will be misconduct on the part of the juror will, as a general rule, be such on the part of an arbitrator. Neither has a right to learn facts except as brought to his attention in the trial." Id. at I73. On the other hand, City of 
the jurymen were chosen because of their knowledge-the courts today seem to forget that in the formulation of rules to govern not only jury trials, but any other determination of fact.

In general, arbitration is of two types: common law and statutory. ${ }^{33}$ The common law arbitration is unsatisfactory; the common law arbitration agreement is revocable, and the award at best is enforceable by suit. Statutory arbitration agreements are irrevocable, and the award is enforceable by speedy motion procedure. The latter type of arbitration is held out as the only type to use by leading experts on the subject, ${ }^{34}$ and there is much propaganda and effort to have statutory arbitration strengthened. The principles of the New York statute have been copied in many states, and are being urged on practically every other legislature in the United States. As Berizzi $v$. Krausz arose under the New York statute, that decision and statutory arbitration in general are of paramount importance in moulding arbitration law throughout this country. ${ }^{35}$

Bridgeport v. Eisenman, 47 Conn. 34 (I879), required that prejudice resulting from the evidence gathered be shown before the award would be set aside. And see The Guldborg, I F. Supp. 380 (S. D. N. Y. I932), wherein the court states that the doctrine of Berizzi v. Krausz does not apply to the use of information gained prior to the hearing.

${ }^{3}$ See Sturges, Comimercial Arbirrations and Awards (I930) Ch. I. There is no statutory arbitration in Oklahoma and South Dakota.

${ }^{34}$ The entire Code of Arbitration of the American Arbitration Tribunal (I93I) for example, is based on this assumption.

$\approx$ See Draft State Arbitration Act, distributed by the American Arbitration Association; Eastman, A Plea for Uniform Lazes on Arbitration (Feb. I929) Magazine of Busrness 142. Pennsylvania adopted the Draft State Arbitration Act in I927, PA. Stat. ANN. (Purdon, I930) tit. 5, \$\$ I6I-I8r. In addition, however, there are three other arbitration acts upon the Pennsylvania statute books: the Voluntary Submission Act, id. $\$ \S ~ I-20$; the Compulsory Arbitration Act, id. \$\$ 2I-II0; and the Reference Act, id. \$\$20I-209; and besides id. $\$ \$$ III-I8o contains certain provisions applicable to all arbitrations. It is thought, however, that most of the arbitrations held in Pennsylvania will be held under the Draft Act; certainly it is the only one whereby a provision in a contract to arbitrate a dispute thereafter arising can be enforced. Cf. Bashford v. West Miami Land Co., $295 \mathrm{~Pa} .560$, I45 Atl. 678 (1928). It is strange that this multiplicity of acts was allowed to stand in the revisions made in 1927. An excellent and thorough treatment of the Pennsylvania arbitration law is contained in Sturges, Arbitration Under the New Pennsylvania Arbitration. Statute (I928) 76 U. OF PA. L. Rev. 345. See also, Seigrist, Construction of the Arbitration Act of I927 (I93I) 35 DICKINson I. REv. 240, condemning the limitation in Grote v. Stein, $99 \mathrm{~Pa}$. Super. 556 (1930), refusing to apply the act to an appraisal. While we agree with the article that the act might well apply to appraisals, we feel that it has overlooked much Pennsylvania law in this connection. See Marcus v. Safeguard Insurance Co., (Ig29) 77 PITTS. LEG. J. 74I. An unusually good court analysis of the arbitration law appears in Katakura and Co., Ltd. v. Vogue Silk Hosiery Co., I5 D. \& C. 389 ( $\mathrm{Pa}$. 193I). While the case was reversed on technical grounds id. nomine, supra note 16 , that does not detract from its excellent exposition. As a matter of fact the Pennsylvania act, copied as it was from the principles of the New York Arbitration law, N. Y. CIV. PRAC. ACT (1920) § 1448-65, will doubtless be subject to the infuence of the New York decisions which certainly are much more pertinent to its construction than are the early Pennsylvania cases decided before I927. The literature on the subject must be used with great care, a great part of it being propaganda, ghost-written or otherwise, and in many ways unreliable. On the other hand, there is some excellent material. STURGES, op cit. supra note 33 , is invaluable to the practitioner or student in the field. Isaacs, Trvo Views of Commercial Arbitration (I927) 40 HARv. L. REv. 929, is very fundamental; while Russell, ARRITRATTON AND AwARD (Aaronson, I2th ed. I93I) is helpful when there are no American decisions on the subject, in showing the English experience under an act similar in many ways to the Pennsylvania statute. 


\section{Rules of Evidence in Commercial Arbitrations-Materiality}

Ex parte examination and the analogous problems raised by Berizzi v. Krausz are but a rather spectacular example of a fundamental problem -the extension of the rules of evidence beyond their original sphere, the jury trial. One could take countless other rules of evidence and write similar expositions thereon-in fact not only the rules of evidence could be treated, but other fact determining proceedings as well as arbitrations could be included. ${ }^{36}$

Several arbitration statutes at the very outset limit the arbiters to a very strict compliance with all the rules of evidence. ${ }^{37}$ For example, the Washington Arbitration Act reads :

"The laws in force in this state relating to evidence. . . shall govern in arbitrations." 38

Such statutes obviously fail to recognize the needs of arbitration or the distinction between business truth and legal truth.

In all jurisdictions the arbitrators are unnecessarily handicapped by evidence rules. "It is plain that the courts do allow considerable latitude in practise at any rate, to the reception of evidence by [arbitrators] but to say as a general proposition that they are not bound by rules of evidence appears to me to be entirely misleading and likely to produce very great injustice." 39 Even in the most liberal states, arbitrators must hear "all

${ }^{23}$ For studies of such questions consult Wigmore, supra note I ; Ross, The Applicability of Common Law Rules of Evidence in Proceedings before Workmen's Compensation Commissions (1923) 36 HARv. L. REv. 263; Sherman, Evidence and Proof Under Workmen's Compensation Lazes (I920) 68 U. of PA. L. Rev. 203; (I9I6) I6 Col. L. Rev. 8I ; (I915) 29 HaRv. L. Rev. 208; (Ig22) 26 id. 79; (Ig23) I8 ILL. L. Rev. 248; (IgI5) I4 MICH. L. REv. 158; (IgI6) I5 id. I75; (I925) 9 MINN. L. Rev. 576; (I9I6) 64 U. OF PA. L. Rev. 325; (I917) $65 \mathrm{id} .377$; (I9I7) 26 YALE L. J. 334. The business aspects of the problems are generally neglected. See McCauley v. Imperial Woolen Co., 26I Pa. 312, 104 Atl. 6I7 (I9I8) and cases following that decision for Pennsylvania rules on the subject. Professor E. M. Morgan maintains that the rules which require opportunity for cross-examination of witnesses and opportunity to meet and refute evidence are not part of the law of evidence but essentials of our adversary system of litigation. (But see supra note 6.) It is possible that we are using the word "evidence" in a very broad sense. We feel, however, that the difference betwen us is one of terminology and classification rather than any particular disagreement as to substance.

${ }^{\sharp 7}$ Arizona, Georgia, Iowa, Maine, Nebraska, Rhode Island, Texas, Washington. The oaths required of arbitrators in many states would seemingly limit arbitrators in their rulings on evidence. See Sturges, op. cit. supra note 33, at 454 et seq.

${ }^{3}$ Wash. Rev. Stat. (Remington, 1932) \$ 427 . The situation in Pennsylvania in this respect is most confusing. PA. STAT. ANN. (Purdon, I930) tit. 28, \$3II, specifically includes arbitration as a judicial proceeding, thereby making many of the rules of evidence in Chapter 2 of Title 28 applicable to arbitrations. On the other hand, PA. Stat. AnN. (Purdon, I930) tit. 5, \& I2I (II) states that the arbitrators have power "to judge the competency and credibility of witnesses and the propriety of admitting any written evidence that may be offered". Qucre whether this allows court review of the arbitrators' rulings and whether the arbitrators would be bound to follow the provisions of Chapter 2 of Title 28 . The matter should have been cleaned up in the revisions made in 1927 . It shows how careful one must be in the field of arbitration; there are many conflicting statutes, and little effort is being made to correct them, except with regard to the propagandists' demand of irrevocability of arbitration agreements.

${ }^{39}$ See In re Enoch and Zaretzky, Bock \& Co.'s Arbitration, [I9Io] I K. B. 327, 336. 
pertinent and material evidence".40 Such a test would be manifestly fair, if the arbitrators were the judge of the pertinency and materiality; but their ruling is subject to judicial interpretation, and courts judge materiality by judicial and not by business standards. ${ }^{41}$ It is in effect adopting a jury standard for business determination of fact. Naturally, unbiased fair arbitrators will admit all evidence which is material to them; if they are prejudiced or unfair their award will be set aside because of that fact.

But it seems ridiculous to require arbitrators to admit evidence merely because it is material for a jury who must judge according to set legal rules, and who must determine fact from their ignorance as enlightened by evidence material according to legal standards. For the arbitrators judge from their own knowledge and according to their own law enlightened by what they feel is necessary for an accurate determination of fact.

Since the more liberal states do not complain if arbitrators admit irrelevant evidence ${ }^{42}$ the net result is the transformation of what should be a speedy, expeditious proceeding, into a lengthy drawn-out affair. Experienced arbitrators have learned it is wise to admit any evidence that

${ }^{20}$ In Mississippi and Missouri the arbitration statute affirmatively provides that the arbitrators shall hear all the allegations and proofs which are material and pertinent to the cause; in Kentucky the arbitrators must hear all testimony offered by either party relative to the matters in controversy; in New York and Wisconsin the arbitrators are affirmatively directed to hear "all the allegations and proofs of the parties"; while in California, Connecticut, Idaho, Indiana, Louisiana, Michigan, Minnesota, Mississippi, Missouri, Montana, Nevada, New Jersey, New York, North Carolina, North Dakota, Ohio, Oregon, Pennsylvania, Utah, Wisconsin and Wyoming the statutes provide for vacation of the award where the arbitrators excluded "pertinent or material evidence". But here, as in the other evidential problems raised below, there must be an offer of proof, and exception taken to the rulings of an arbitrator before the award can be upset for an evidential error. See, for example, Donahue \& Son v. Barclay, White Co., Inc., 9 D. \& C. 303 (Pa. I927) ; Ketcham v. Odd Fellows, supra note I5; Hewitt v. Lehigh \& Hudson River Ry., 57 N. J. Eq. 5II, 42 At1. 325 (I899). Before the passage of the Draft Act in Pennsylvania the arbitrators had much broader powers with respect to evidence. "They were constituted by the parties the ultimate judges of the competency of the witnesses and of the admissibility, weight, and relevancy of the evidence; ..." March v. Lukens, 214 Pa. 206, 209, 63 Atl. 427, 428 (Ig06).

sl Cf. McLaurin v. McLauchlin, 215 Fed. 345 (C. C. A. 4th, IgI4) ; Pacific Lime \& Gypsum Co. v. Missouri Bridge \& Iron Co., 286 Mo. II2, $226 \mathrm{~S}$. W. 853 (I920). It is true that materiality is intimately connected with substantive law. But here, it must be borne in mind that the laze in an arbitration is what the arbitrators decide it to be. An error in law on their part will not vitiate an award.

${ }^{19}$ Of course, in the less liberal states where the arbitrators must follow legal rules of evidence absolutely, they are generally all at sea in their rulings, and harassed by any objection made to evidence. In Rhode Island, $e . g$., an award will be vacated if they admit "legally immaterial evidence". Cf. Bivans v. Utah Lake, Land, Water, and Power Co., 53 Utah 6or, I74 Pac. II26 (I9I8).

Oftentimes what is immaterial legally may be very material from a "business-arbitral" viewpoint. Cf., e. g., the arbitration rules of the American Spice Trade Association providing for the admission of previous offers of settlements if in writing to determine who should pay the costs of the arbitration. Note also the odd Business Statute of Frauds.

In general the admission of incompetent evidence by an administrative tribunal will not prove fatal. Tagg Bros. v. United States, 280 U. S. 420, 50 Sup. Ct. 220 (1930). But uniike the general arbitration rule, the administrative tribunal must have some evidence to support its findings, and cannot rely on its own knowledge entirely. See Chicago Junction Case, 264 U. S. 258, 263, 44 Sup. Ct. 317, 319 (1924) ; Interstate C. C. v. Union Pac. R. R., 222 U. S. 54I, 547, 32 Sup. Ct. IO8, III (I9II). Cf. Faris, Judicial Notice by Administrative Bodies (1928) 4 IND. L. J. I67. 
is offered, and then privately to consider what they please. ${ }^{43}$ For their decision in weighing the evidence ${ }^{44}$ and their law of the case is final. ${ }^{45}$

The case of Levy v. Shamrock Construction Company ${ }^{46}$ consumed nine days, because the arbitrators, all outstanding building experts, were forced to listen to testimony of other building men regarding their opinion and viewpoints on the construction of a building which the arbitrators had previously examined. Had the arbitrators been safely able to exclude such evidence, the arbitration would have been over in a few hours. Legally, the evidence was competent, actually the arbitrators, being human, needed none but their own opinion to guide them. And that was all they used! In Fay v. DuPuis, René-David and Company ${ }^{47}$ the plaintiff alleged the defendant brokers had wrongfully closed a margin account. The contract presented by the plaintiff showed that the broker had the right to make the sale. Fay argued that he could show a waiver-the defendant had allowed him and many others more time than was specified in the margindemand wire on previous occasions. The contract, by its terms, was specific in providing that previous waivers were of no effect. "When you deal in securities, you must play the rules as announced in your contract," said the board. The clerk of the arbitration prevented them from giving a formal decision then and there, and persuaded them to listen to all the evidence the plaintiff offered for several days. The board returned a verdict for the defendant, grumbling as they did so that their minds were made up as soon as they read the contract. To them as final judges the facts which the plaintiff presented were clearly immaterial - but to a court viewing the case with a legal eye the evidence would have been clearly material. I do not hold this out as a very fair case; the arbitrators might have been wrong in their ideas of waiver, but assuming they were going to decide the way they did, why should they be compelled to listen for days to evidence they knew would have no effect on them?

${ }^{43}$ Cf. Code of Arbitration of the American Arbitration Tribunal (ig3i) il8: "It is a safe rule for the arbitrators to admit any evidence which may have a bearing on the case." But note if the admission of immaterial evidence goes to such extremes that the arbitrators are prejudiced thereby or award on matters not submitted, the award may be vacated. Cf. Austin v. Clark \& Crump, 8 W. Va. 236 (I875).

The dangers, however, of failing to admit evidence which might be pertinent in the court's opinion is illustrated by Marr v. Marr, I03 Pa. 463 (1883). The courts will often decide that the "examination is inadequate and the conduct of the arbitrators arbitrary", and set aside the award. Witmer v. Royal Insurance Co., 33 LANC. L. REv. 345, 350 (IgI6). On the other hand, when too much immaterial evidence is admitted, to "play safe", we have the situation described in Campbell v. Rockey, 40 C. C. I77 (Pa. I9I2): "The history of this action illustrates how futile are many of the experiments and devices to improve upon the trial by jury and the order of the procedure of our courts as now constituted."

1 Itoh and Co. v. Boyer Oil Co., 198 App. Div. 88I, 19I N. Y. Supp. 290 (I92I); Boomer Coal \& Coke Co. v. Osenton, IOI W. Va. 683, I33 S. E. 38I (I926).

s See infra p. 246.

${ }^{46}$ The names in the arbitration cases herein cited are fictitious, but the facts are authentic.

${ }^{47}$ Cf. Hart v. Kennedy, 47 N. J. Eq. 5I, 20 Atl. 29 (I890). 
The determination of the two general headings of evidence-materiality and relevancy-should be for the arbitrators, if no prejudice is shown. Of course the parties should have the right to be heard, and the right to cross-examination of the evidence presented by the opposing side should be present, ${ }^{48}$ though if the parties are willing to waive it, such waiver will be respected by the courts. ${ }^{49}$

\section{Rules of Evidence in Commercial Arbitrations-Competency}

The other general evidence heading, competency, offers more difficulties. The courts generally say that the arbitrators, knowing no legal rules, cannot be held to strict accounting on this score. ${ }^{50}$ Many competency rules are designed to protect the unsuspecting jury from seemingly sound evidence with but little probative force. With these the business arbitrators need not be concerned; they can do their own weighing. Hearsay, discreetly weighed, can be immensely valuable. ${ }^{51}$ On the other hand, there are many rules of competency which are adopted for reasons of public policy, irrespective of jury trial. These the arbitrator should be forced to respect. For instance the physician-patient privilege should apply to arbitrations as well as jury trials. Georgia is the only state with specific statutory provisions regarding competency in arbitration. ${ }^{52}$ One Michigan case considered the physicianpatient privilege and because of the peculiar mandatory wording of the statute regarding it, held that a fraternal organization in a proceeding somewhat analogous to an arbitration could not consider the physician's testimony. ${ }^{53}$ The case is unique, however, and the question of public policy behind competency rules does not seem to have occurred to the courts in connection with arbitrations. ${ }^{54}$

An examination of specific problems raised by particular rules of evidence in the light of usage in arbitrations is most constructive. The parol evidence rule is an enigma to law students, worried as they are as to whether it is a question of substantive or adjective law. Professor Nathan

25ana v. Dana, 260 Mass. 460 , I57 N. E. 623 (I927).

${ }^{90} \mathrm{MIcD}$ onald v. Real Estate Board of Baltimore, I55 Md. 377, I42 At1. 26r (I928).

co "Arbitrators are not usually lawyers, and a rule making the validity of their award depend on the legal correctness of their action upon the competency of testimony would operate to defeat the purpose of the statute on that subject." Lumbard v. Holdiman, II5 I11. App. $458,46 \mathrm{I}$ (1904).

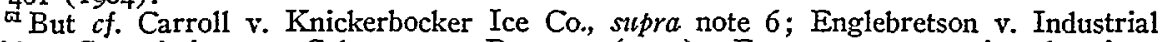
Accident Commission, 170 Cal. 793, I5I Pac. 42I (1915). For a case supporting the viewpoint of the text see Anderson Trading Co. v. Brimberg, IIg Misc. 784, I97 N. Y. Supp. 289 (I922). But see McCauley v. Imperial Woolen Co., supra note 36 . "Whatever foundation there may be for objections to the rule excluding hearsay in its full extent, it must be admitted that there is still a large residuum of necessary protection involved in it." See Standard Oil Co. v. Mealey, I47 Md. 249, 254, I27 Atl. 850, 852 (1925). Cf. Note (1926) 24 Mich. L. REv. 83I.

${ }^{5}$ GA. Code ANN. (Michie, I926) §504I; and see supra note 33. $\left(\mathrm{IgO4}_{4}\right)$

${ }^{\infty}$ Dick v. Supreme Body of the International Congress, $x_{3} 8$ Mich. 372 , ror N. W. 564

Cf. Hickman v. London Assurance Corp., I84 Cal. 524, I95 Pac. 45 (I920); Chafee, The Progress of the Law (1922) 35 HARv. L. REv. 683, 684, 685. 
Isaacs explains it simply to his students in business by pointing out that when the parol evidence rule prevents oral testimony from getting to the jury, it is operating as a rule of evidence; when the judge considers it in his rulings, he is using it as substantive law. Arbitrators, judging from experience and records in many arbitrated cases, refuse to admit oral testimony concerning written documents to an extent unknown in law. Untutored in the intricacies of it, they believe the parol evidence rule is absolute; to them it is a rule of substantive law, or in their own minds "business law". They, as final judges of the law and facts, should not be held accountable for a rule which is partially substantive and partially a rule to prevent juries from running contra to substantive law. In the few times the question has been presented to the court as to the effect of the parol evidence rule on arbitrators, we find little light. One case said the matter was a question of the law of evidence and hence in the discretion of arbitrators; ${ }^{55}$ another, after a lengthy legal discussion, showed as a matter of complicated law that the arbitrators were correct in their ruling. ${ }^{56}$

Suppose in an arbitral hearing a witness's memory proves blank and attempts are made to revive it by the use of documents and then efforts are made to introduce the record of the witness's past recollections. Suppose, on the other hand, the attempt is made only to refresh a witness's memory. It is obvious that business men cannot distinguish between the two and, as a practical matter, will cut corners by politely requesting the witness to let them see the papers in any event. Qucere if the law should allow them to do so. One court held that allowing the arbitrators to see records of a writing merely refreshing a witness's memory was grounds for vacation of the award; ${ }^{57}$ while another held that even the examination of the entire file of documents in a party's possession was not fatal. ${ }^{58} \mathrm{It}$ is submitted that the latter decision is sounder from the business viewpoint and the former justified only if we deem the arbitrators to be analogous to jurors.

The courts which adopt the view that the entire matter of evidence, except materiality, ${ }^{59}$ is for the arbitrators, find hardship in other ways. Suppose, for example, that a party seeks to attack a judgment presented as evidence in an arbitration on collateral grounds, clearly it is against public policy to allow arbiters as well as juries to pass on their merits, and yet one court allowed the arbitrators to do so ${ }^{60}$ holding that the only time the court

* Brodhead-Garrett Co. v. Davis Lumber Co., 97 W. Va. 165, x24 S. E. 600 (I924).

${ }^{6}$ In re Curtis and Castle Arbitration, 64 Conn. 501, 30 At1. 769 (I894).

or Matter of di Martino v. Guarnera, N. Y. L. J., February 25, I926, Sup. Ct. N. Y., Bronx County.

${ }^{6}$ In re American Trading Company, supra note 32 ; and $c f$. Beall v. Board of Trade, 164 Mo. App. I86, I48 S. W. 386 (I9I2), refusing to vacate an award because the arbitrators considered documents used by a witness to refresh his memory.

wo Johnson v. Noble, I3 N. H. 286 (1842).

${ }^{\infty}$ Baker v. Merrifield, I3 N. H. 357 (1843). 
would interfere with arbiters was when they excluded material evidence. Suppose arbitrators entirely reject a book of accounts under circumstances which would make it admissible in a court of law, or suppose they admit a book of accounts under circumstances, for example to prove a debt, which would clearly bar its admission before a jury. Courts have sustained arbitrators in both these instances. ${ }^{61}$ And rightly, for men trained in business need not worry about the pitfalls which would encompass the jury were they to consider accounts promiscuously. ${ }^{62}$ Should the rules regarding proof of documents apply? Clearly not, unless adopted for public policy, such as the stamp rules in England. Neither should arbitrators, experts themselves, be handicapped by our narrow rules regarding opinion evidence. ${ }^{63}$

It certainly is clear that the rules of courts regarding evidence should not be applicable to arbitration, yet in Georgia they are made applicable by statute. $^{64}$ One Maine case, in discussing the question, held that it would be inexpedient as well as impractical to compel arbitrators to be held to rules of court concerning evidence. ${ }^{65}$

There is a lesson to be derived from the struggles of arbitrators to free themselves from the laws of evidence. Lawyers should not frown too heavily upon the logic used by the business man in his pursuit of busiiness truth. Arbitration, except where there is no question of law at issue, is at best a stop-gap. Merchants' courts were historically the place where merchants were forced to settle their disputes. The law then gave them redress. Merchants' courts disappeared. But today merchants are so dissatisfied with the law's procedure that they again are turning to their own tribunals. Naturally, the law which offers such unsatisfactory remedies to business should offer no resistance to this; it should not compel business to settle its disputes in courts, but it should clean its own house and make its courts fit the needs of modern business. ${ }^{66}$ And meantime it should allow business men to conduct their own tribunals in a business-like manner.

a Tyblewski v. Svea Fire and Life Assurance Co., 220 Ill. 436, 77 N. E. Ig6 (I906); Mulder v. Cravat, 2 Bay 370 (S. C. I802).

${ }^{\infty}$ But see the typical liberalized book of account statute of Michigan, MrCH. Comp. LAws (1929) $\$ 14207$. The hearsay rule is much modified, both as applied to trials and arbitrations. The modification, however, does not apply to certain types of businesses. Yet an arbitrator, expert in one of the latter types, should be allowed to utilize books of accounts according to his business experience. See Pennsylvania statutes cited stupra note 38 .

${ }^{\infty}$ But see Hursh v. Gross, 2 York Leg. Rec. I75 (Pa. I88I).

"The examination of witnesses and the admission of testimony shall be governed by the rules of the superior court." GA. CODE ANN. (Michie, I926) §5042.

w Waterman v. Merrow, 94 Me. 237, 47 Atl. I57 (1900).

co "You and I would be dereliçt in our duty as lawyers and as judges if we attempted to meet the problem of eradicating the defects in the administration of justice merely by resorting to arbitration because of these defects and these delays." Mack, Lectures on Legal Topics (r929) 7 Association of the Bar of THE City of New YoRk IO7. 


\section{$V$. Rules of Law in Commercial Arbitrations}

In Great Britain, much more freedom is allowed arbitrators in their methods of ascertaining facts; but a method is provided for court instruction of the arbitrators on the law to follow in their decisions. on the facts. ${ }^{67}$ As was said in Czamikow v. Roth, Schmidt \& $\mathrm{Co}^{68}$ :

"That they (arbitrations) will continue their present popularity, I entertain no doubt, so long as the law retains sufficient hold over them to prevent and redress any injustice on the part of the arbitrator and to secure that the lawe that is administered by the arbitrator is in substance the law of the land, and not some homemade law of the particular arbitrator or the particular association." (Italics inserted.)

We in turn handicap our arbitrators in their methods of discovering facts, but allow them full play in their decisions on the law. ${ }^{69}$ Those prominent in the advocacy and propagandizing of commercial arbitration would have it this way. ${ }^{70}$ But in so doing they render arbitration even more of a stopgap than ever.

\section{Trade Associations and Arbitration Rules-Effect of N.R.A.}

Arbitration in the United States today is roughly of three species:

(a) The casual unsupervised arbitration, informal, arranged with but little thought to detail and administration. It is conducted by the parties

${ }^{\sigma}$ North \& Southwestern Junction Ry. v. Assessment Committee, etc., I3 App. Cas. 592 (I888); see ArbitRation ACT, $52 \& 53$ Vict. c. $49, \$ \S 7$, I9 (I889). But cf. Arbitrator Taking Evidence in Party's Absence (I93I) $72 \mathrm{~L}$. J. I44.

${ }^{a}$ [1922] 2 K. B. 478,484 .

${ }^{\infty}$ Cf. Fudickar v. Guardian Mutual Life Ins. Co., 62 N. Y. 392 (I875) ; Itoh \& Co. v. Boyer Oil Co., supra note 44. In Alabama, Illinois, Iowa, Kansas, Minnesota, Nebraska, Oregon, and Washington, however, awards not in accordance with the law will not be enforceable. In Illinois, Nevada, North Carolina, Utah, and Wyoming, provision is made for the reference of questions of law by the arbitrators to courts, and similar limited provisions exist in Connecticut and Massachusetts. Note, however, the following provision in the Pennsylvania act: "The arbitrators, or the parties to the arbitration with the approval of the arbitrators, shall have the right to apply to the court, at any time during the arbitration proceedings for the determination of any legal question in accordance with the terms of the Uniform Declaratory Judgments Act. Such an application, however, shall not operate as a stay; of proceedings, unless the said arbitrators consent to such stay of proceedings." PA. Stat. Ann. (Purdon, 1930) tit. 5, § I77. Except for Snow v. Schulman, 352 I11. 63, 185 N. E. 262 (1933), there is no American law on this or similar provisions. The English cases on a somewhat similar statutory provision can be found in Russel, op. cit. supra note 35, I49-160, 314-321. Cf. Grinnell, Functions of the Superior Court in Regard to Awards Under the Massachusetts Conmercial Arbitration Act of 1925 (1926) II MAss. L. Q. 4.

${ }^{70}$ The present trend is to pass statutes following the New York act, the so-called DRAFT State Arbitration Act, supra note 35. The Commissioners' Arbitration Act, in force in Nevada, North Carolina, Utah, and Wyoming, providing for reference of questions of law to the courts following the English practice, is bitterly opposed by the proponents of the Draft Act, which has been recently adopted in twelve states (Arizona, California, Connecticut, Louisiana, New Hampshire, New Jersey, New York, Ohio, Oregon, Pennsylvania, Rhode Island and Wisconsin). These Draft Acts, well propagandized and ably fought for, are certain to spread, and even when unsuccessful in the passage of the Draft Act, its proponents are uniformly successful in preventing the passage of the Commissioners' Act. 
and arbitrators themselves. Even the most earnest advocates of arbitration admit that such arbitrations are failures. ${ }^{71}$

(b) The trade arbitration, its success depending on the type of trade association supervision given. But this type is satisfactory only for members of a trade group, and it is doubtful if a permanent solution of business difficulties can be found in such functionalization. Certainly trade association arbitrations will not furnish a solution for business at large or for consumers in general.

(c) Supervised arbitrations before bodies specializing in arbitration technique; e. g., Chambers of Commerce, The American Arbitration Association, etc. Some associations have built up a very thorough code for the conduct of arbitrations. They are handicapped by the law of evidence, and while proclaiming their success in propagandized publicity, privately admit that they too are but a "stop-gap" and are seeking a hinterland to support tribunals for the settlement of commercial controversies. Many follow a very informal type of procedure, but the trend seems to be towards making an arbitration more or less analogous to a trial, with dockets, pleadings, depositions, and counsel present to present facts in true legalistic style. ${ }^{72}$

The National Industrial Recovery Act has focused sharp attention on the use of trade association and supervised types of arbitration in the settlement of commercial disputes. In many trades every effort is made to cause merchants to submit their contractual disputes to arbitration ; ${ }^{73}$ many Codes of Fair Competition provide for arbitration. ${ }^{74}$ These arbitrations

" See Code of Arbitration of the American Arbitratton Tribunal (I93i) Ch. I.

rId. Ch. VI. Even the order of the proceeding is made to resemble trial. See, for example, Rules of the American Arbitration Tribunal: "The order of the proceedings shall be the recording of a Minute, setting forth the presence of the arbitrators and parties, the statement of the claim and of the answer, and the arrangements made for the hearing. The complaining party, or his counsel, shall then present his case, call his witnesses and present his proofs, and then submit to questions and examination on the proofs presented. The defending party, or his counsel shall then present his defense, call his witnesses and present his proofs, submitting to questions and examination thereon. Exhibits offered by either party may be received by the arbitrators, shall be marked for identification and made part of the record."

${ }^{\pi}$ Even where the Codes do not contain such provision, the adoption by trade associations of standardized contracts as a result of the N.I. R. A. will prove a great source of arbitration, as many of these contracts will contain provisions for compulsory arbitration. Cf. ARBITRATTON - Provisions in Uniforar Sales or Purchase Contracts, published by the American Arbitration Association (1933). Even before the present economic set-up many trade associations required their members to arbitrate disputes with each other; see, for example, Grain Dealers' National Association, Cocoa Merchants' Association of America, National Pickle Packers' Association, American Cotton Waste and Linter Exchange. Some of the other trade association arbitration set-ups were unfair and were not enforced by the courts on the ground of restraint of trade. Paramount Famous Lasky Corporation v. United States, 282 U. S. 30, 5 I Sup. Ct. 42 (1930) ; Sono Art-World Wide Pictures, Inc. v. Lando (I93I) 79 Prrrs. Leg. J. 5 I8; R. K. O. Corp. v. Moody (1932) 80 Pitts. Leg. J. 40r. Cf. Birdseye, Arbitration and BusINESS ETHICS (I926).

${ }^{74}$ See, for example, the Codes of the Cotton Textile Industry, the Crushed Stone and Gravel Industry, Retail Lumber and Building Supplies, Wool Textile, Automatic Sprinklers and Textile Machinery, Corset and Brassiere Industry. See also the account of the proposed arbitration clause in the Millinery Code, (I933) I U. S. WEekLY L. J. 429. The provisions in the Codes range from providing for arbitration in the matter of cost adjustment in pre- 
almost without exception are held under prearranged arbitration rules, ${ }^{75}$ and in view of the interest in the subject we have examined a large number of these rules with respect to the problems here raised. ${ }^{76}$ Most rules, unfortunately, fail to recognize the evidential problem at all. The most frequent mention of rules of evidence is to contrast the business method of ascertaining fact with "technical rules of evidence". ${ }^{77}$ The main idea seems to be to stigmatize legal rules without considering how a business determination of the facts should be reached, or how to help the arbitrators to determine fact. The rules vie with each other in emphasizing the necessity of admission of all pertinent evidence ${ }^{78}$ or the exclusion of irrelevant evidence, ${ }^{79}$ but the two are infrequently synthesized. ${ }^{80}$ Occasionally, the arbitrators are made absolute judges of what is necessary as evidence; ${ }^{81}$ in other instances they are allowed to make their own rules of evidence, and sometimes their decision on these matters is said to be final..$^{82}$ Occasionally, a more or less complete set of evidential rules is adopted. These, however, are uniformly poor, and show little comprehension of the nature of the task involved, as an examination of the example set forth will show. ${ }^{83}$ The

existing contracts made necessary by the passage of the N. I. R. A. to the arbitration of all disputes within a trade of a commercial nature. In a few instances effort is being made to provide for arbitration as a method of enforcement of Codes.

${ }^{7}$ Arbitration is a procedure with which most trade groups are familiar, and in many instances the adaptation of existing arbitral machinery will be sufficient, thus necessitating no new and untried methods. See ARBitration Provisions in Codes of FaIr Competrtion, published by the American Arbitration Association (1933).

${ }^{7 B} \mathrm{~A}$ complete collection of arbitration rules of the various trade associations is contained in YEAR Book on Commercial ARBItration, op. cit. supra note iz.

$\pi$ See, for example, the arbitration rules of the American Bleached Shellac Manufacturers Association and American Cotton Waste and Linter Exchange. See also McCauley v. Imperial Woolen Co., supra note 36 , showing the interpretation the courts place on the phrase "technical rules of evidence". See, however, the statement in the Arbitration Provisions of the United Typothetæ of America: "While the board may not be bound by legal rules of evidence, it will exclude matters obviously unrelated, which are time consuming, or which becloud the issue; but all evidence bearing on the case will be freely admitted. Proof is not restricted to legal rules of evidence. Liberality of procedure is to be observed, and such methods will be followed as will be best calculated to elicit all the evidence pertaining to the case and at the same time meet the convenience of the members of the board and the parties at issue." This should be carefully analyzed and compared with the doctrines previously advanced in the text.

${ }^{\approx}$ See, for example, the Rules of the American Arbitration Tribunal, Board of Trade of the City of Chicago.

T2 The common provision is "all irrelevant or unimportant matters shall be excluded". Association of Cotton Textile Merchants, Chamber of Commerce of State of New York Arbitration Rules.

80 "The arbitrators shall receive all the evidence bearing on the issue but may exclude matters obviously unrelated which are time consuming and tend to becloud the issue. They will not be bound by legal rules of evidence." Arbitration Rules of National Standard Parts Association, American Bottlers of Carbonated Beverages.

s1 "The hearing shall continue until the arbitrators are unanimously agreed that all evidence necessary to a decision has been submitted." Arbitration Rules of the National Confectioners Association.

sa "Their admission and rejection of testimony shall be final." American Bleached Shellac Manufacturers Association.

${ }^{3}$ E. g." "All interrogatories by contestant shall be put by only one person on each side, unless by consent of the arbitrator or arbitrators. The cross-examination of witnesses need not be confined to matters testified to in the direct examination, but can be extended to any matters necessary to make out the case of the party making the cross-examination. The 
truth of the matter seems to be that the professional sponsors of arbitration have, rightly or wrongly, devoted so much attention to the procuring of laws to make for the irrevocability of the arbitration agreement ${ }^{84}$ or of making certain that a particular trade association will administer the arbitration, that they have neglected the procedural side-which to us is the far more important one-with rather sad results. ${ }^{85}$.

\section{Standardized Contracts and Unstandardized Awards}

There had been a great impetus, even before the National Industrial Recovery Act, towards supervised arbitration resulting from the use of standardized arbitration clauses in standardized contracts. The arbitration clauses in such contracts are generally inserted because of the dissatisfaction by business with court methods, though occasionally to prevent wild claims particularly effective before juries, for example in stock-brokeragecustomers or warehousing contracts. But paradoxically enough, there has been little standardization in results of the arbitrations, and effort is made to prevent decided cases from being precedents. ${ }^{86}$

A series of warehouse cases will illustrate the last statement. The Clarke Warehouse Company had several warehouses, only one of which was fireproof. Its advertising matter and moving vans were gaily decorated with the fireproof structure, and the wording of the former would lead prospective customers to believe their goods were safe from all fire hazards when stored. Their standardized contract provided, in small type, that the company could store in any of its warehouses unless otherwise specifically directed in writing, and the company under no circumstances would be liable for fire loss. One of its non-fireproof warehouses was destroyed by fire, and court trials were prevented by the presence of an arbitration

re-examination shall be strictly confined to new matter introduced in cross-examination. Witnesses shall be permitted to testify as to facts within their own personal knowledge, and cannot be allowed to state information given them by others. The testimony must be confined to the matters in controversy, and all irrelevant facts must be excluded. No impeachment of the general reputation of a witness for veracity shall be permitted. Proof of agency must be established before the admission of an agent can be received. The arbitrator or arbitrators shall have the right to dismiss any case where the conflict in the testimony is such that it may be deemed improper to give a decision." Rules of the Cincinnati Hay and Grain Exchange.

${ }^{3}$ See Phillips, The Paradox in Arbitration Laze (I933) 46 HaRv. L. Rev. I258.

s Thus arbitration has not spread in the United States as was predicted. The failure or success in a particular trade most frequently depends on the personality and knowledge of the secretary of the trade association involved. Arbitration has become too much a matter resting on personalities and not enough on general economic and legal principles. For example, even the success of the American Arbitration Tribunal is due primarily to the fact that the clerk of that tribunal is possessed with an unsurpassed knowledge of arbitration procedure, and a personality which immediately gains the trust, admiration, and respect of both participants and arbitrators. Without $J$. Noble Braden, its clerk, the American Arbitration Tribunal would have achieved little of its success. In fact, outside of New York, where Braden holds forth, it has been uniformly unsuccessful in obtaining arbitration cases.

${ }^{80}$ Code of Arbitration of the American Arbitration Tribunal, op. cit. silpra note 34 at I22. And see the scathing indictment of the Draft State ARBITRATION ACT and modern arbitration on these grounds in the Second Report of the Texas Civil Judicial Council (I930) iol-iog. Cf. Williston, Some Modern Tendencies of the Law (ig29) 56 et seq. 
clause. The variety of results reached by arbitrators on the same set of facts as presented in different cases was limited only by the number of possibilities. One board flatly decided that the provisions on the contract governed and allowed no recovery; another refused to consider the fire limitation and allowed full recovery; another thought that the burden of proof was on the plaintiff to prove deceit by the advertising; another that the burden was on the defendant to prove that the advertising was not misleading. One rather prominent New York lawyer advised his client to accept a nominal settlement on the ground that the terms of the contract obviously prevented recovery before a board of arbitrators. The results of the previous cases were private, and, alas, he was never informed of his error. Arbitration in standardized contracts may be desirable to avoid legal logic for the determination of business facts, but it can never achieve standardization of result. The merchants' courts of the Middle Ages, which were absorbed by the law because public policy dictated that there be but one system of jurisprudence, at least had but one set of rules of law for the decisions of their cases. Arbitrators have a myriad of them, uncontrolled as they are in their decisions of law. The English say: "There must be no Alsatia in England where the King's writ does not run". ${ }^{87}$ But in the United States each arbitration board may sit in an Alsatia all its own and decide as it will. Yet who can complain when business men turn in desperation to private tribunals because of the antiquated method of fact determination used by the courts? What seller of skewers would desire an unintelligent jury to pass on their quality, where probably none of the jury ever heard the word "skewer" before the facts of the case were presented?

\section{Conclusion and Herein of Proposed Solution of Business Sessions}

It is not enough for the law to permit business arbitrators to find facts as they deem "business logic" dictates, nor is any permanent solution evolved by teaching and allowing business men to build up a proper arbitration procedure by contract. The law should provide business men with courts which can determine business fact. It is proposed that a special "business session" be provided in our larger cities, at least, where the "trial" can be conducted along business lines. The parties can be at liberty to select their own judges of the facts from business experts. Where they are unable to agree on these expert "fact triers" the court or "Registrar of Business Judges" should be able to appoint them from selected panels of experts in the particular field of dispute. These experts could determine the "business facts" in a "business manner" with very limited court control and without court supervision. The facts as found would be the subject of legal application of legal rules by the court-which could adopt reforms in law heretofore

${ }^{87}$ Czarnikow v. Roth, Schmidt \& Co., supra note 68, at 488. 
prevented by stare decisis. While the courts might be reluctant to break away from anachronisms when dealing with juries, they would have a good excuse to adopt new rules of law to apply to business facts in cases where the rules of law do not work justice in modern business. The business man could still eat his cake, and the lawyers could have it too. ${ }^{88}$ The former would have his facts and "business logic" as a basis of determination of "business truth"; the latter the standardization and similar application of law to equivalent circumstances.

This business session would be open only to those who agreed thereto, and only to true commercial cases. It could be made as speedy and private as business men demanded. Those who still preferred a trial by "jury of their peers" would be able to obtain it. But it is submitted a "business session" would take much litigation away from the crowded jury sessions and cases demanding a business solution would be properly solved.

If "business judges" in finding facts were held to the same rules as referees little would be gained; but they should not be. True, there need be many safeguards built up, and new special rules of evidence developed. Berizzi v. Krausz would not apply. Business judges would still use their own knowledge of situations. Little restriction would be placed on hearsay evidence. Public policy rules would be kept. The evidence problem should be the subject of research and careful analysis, and business philosophers as well as legal technicians should be consulted in the progress.

There can be no doubt that many of our legal tools are insufficient and ineffective. There can be no question that business is dissatisfied with them in many ways, and among them is the trial as now provided. Business men left alone decide their disputes by business logic in ascertainment of business facts. Let the law adopt the business methodology for the determination of business disputes, and supplement it by rules of law in regularly constituted courts - a thing the business man cannot and will not do alone or in arbitrations. Each can thus learn the other's language and come to speak it.

${ }^{\&}$ Of course where there is not even legal frosting on the cake the business man need save none for the legal profession. Thus in a dispute which is purely factual, or where the parties and arbitrators all agree on the legal solution once the facts are found, there is no reason for arbitration to be displaced, no reason for courts or lawyers to interfere. It is really in this sphere that arbitration has its place, a solution for a determination of pure business fact, uncomplicated by law. When it attempts to deal with law it is a stop-gap, and an eventual failure. See Nordon, Arbitration (1926) I62 L. T. 262, and the Reports of the Meeting of Solicitors' Managing Clerks Association (I93I) I72 L. T. 455. 